\title{
Interpersonal Metadiscourse Markers and Appraisal Portrayed in BBC's Corona Virus News Report
}

\author{
Achmad Firdaus ${ }^{1, *}$ Mira Shartika ${ }^{2}$ \\ ${ }^{1}$ Department of English Literature, Universitas Islam Negeri Maulana Malik Ibrahim Malang, Indonesia \\ ${ }^{2}$ Department of English Literature, Universitas Islam Negeri Maulana Malik Ibrahim Malang, Indonesia \\ *Corresponding author. Email: afirdaus77.af@gmail.com
}

\begin{abstract}
The current pandemic study has not been much discussed, especially one focusing on interpersonal metadiscourse markers and appraisal use. Consequently, this study is significant in reporting the descriptive analysis of the features of interpersonal metadiscourse markers and appraisal appearing in the BBC News reports that discussed Corona Virus. A discourse analysis approach is used to examine the interlocutors' phenomena of metadiscourse within the discourse. The study results revealed that the way the speaker delivered the argument was denoted by the presence of interpersonal metadiscourse markers to convey a message. Thus, it demonstrated the way the speakers attempted to engage the listeners in the discourse. Moreover, the findings also revealed that the appraisal framework's application contributed to the markers formerly being analyzed. Consequently, it elucidated how the speaker delivered their arguments by applying evidential, hedges, boosters, attitude markers, and self-mention.
\end{abstract}

Keywords: BBC News, Interpersonal Metadiscourse Markers, Appraisal Theory.

\section{INTRODUCTION}

Pandemic CoViD-19 has changed human life, especially in the case of communication. People need to focus on comprehending various information they have received. Therefore, this paper aimed to investigate the interpersonal metadiscourse markers found in the British Broadcasting Corporation (BBC) News reports that discussed Corona Virus. It was conducted to understand the way people applied the features of metadiscourse to construct their meanings within the discourse. Hence, it is useful to understand the discourse comprehendingly regarding the information of Corona Virus.

It has been almost a year since the virus appeared in Wuhan. At that time, several perspectives came from the whole society in responding to the virus outbreak. Thus, it causes the emergence in providing reliable information for the society. Meanwhile, metadiscourse can provide insights to conceive the proper meaning to avoid misunderstanding in interpreting the information. Besides, this paper attempted to examine the speaker's information through the news report to grasp the intended meanings portrayed by the speaker easily.

Additionally, this inquiry was also made by applying the appraisal framework to inspect the interpersonal metadiscourse markers. Metadiscourse is a general concept applied in discourse analysis to conceptualize the interaction between the writer, texts, and reader [1]. Similarly, metadiscourse is concerned with the language used to arrange the discourse within the text and get the audiences involved in the text. Furthermore, the concept of metadiscourse can be defined as the interaction which is deliberately created by the writer by way of the written language to engage the readers [2]. It is the way the writer attempts to connect with the reader throughout speaking. Moreover, by using metadiscourse, the writer projects himself into the discourse to beckon his manner towards both the text and the reader.

Generally, numerous people apply language as a means of communication without knowing that they use the concept of metadiscourse. Previously, language becomes a crucial part of human's relationship with one another. It is used to engage the humans within the discourse in a particular context. Discourse is the utilization of language in a specific context followed by meaning and conducted by actions [3]. For instance, the language used by the news presenter attempts to bring out the sense of persuasions. 
In contrast, it is different from the way ordinary people have a conversation. With one another, the language used in the society is a language for daily conversation context. In delivering information, people use a particular way to express ideas and construct the discourse. Therefore, the arrangement of words or phrases is certainly different within the discourse. Thus, the use of words, phrases, and parts of sentences that refer to a range of rhetorical features can be identified through the metadiscourse marker, which inspects the features of the discourse in communication [2].

Several studies had been conducted by several researchers that are concerned with metadiscourse markers. They attempted to investigate the features of metadiscourse in various content of news [4] [5] [6] [7] [8] [9]). Aside from the relevant studies mentioned before, the researcher also applied the appraisal theory [10]. It deals with the explanatory approach to investigate, portray, and elucidate how language is utilized to assess feelings or values, adopt stances, create textual personas and arrange the position and relationship of interpersonal [10].

By following the previous studies mentioned before, this inquiry's gap is to discover metadiscourse in online news reports. Hence, this inquiry aimed to inspect the occurrence of metadiscourse [2]. Thereof, it focused on the concept of interactive and interactional metadiscourse. It was also supported by the concept of appraisal [10]. Therefore, this article was purposed to understand the phenomena of metadiscourse in the BBC News reports and to analyze further the interpersonal metadiscourse markers.

\section{THEORETICAL FRAMEWORK}

This section covers several theories relevant to this present inquiry involving metadiscourse and appraisal theory, which deals with several domains that might contribute to interpersonal metadiscourse markers.

\subsection{Metadiscourse}

The functional analysis principle refers to metadiscourse as the writer or the reader's interaction with the text. Then, he employs Thompson and Thetela's framework dealing with the differences between interactive and interactional resources to recognize the organizational and evaluative features of interaction [2]. Therefore, a new model of metadiscourse has been created by combining their conception, and it is also added by including the earlier model of metadiscourse.

\subsubsection{Interactive Metadiscourse}

Interactive metadiscourse concern the author's understanding of existing audiences and how to project them through proportional information. It simply means that the author needs to create the text coherently and convincingly. It is done to guide the receiver through the text, and it is useful to shape and limit the content to find the needs of a particular receiver so that they will comprehend the author's means and goals. Further, it provides the author to organize the information flow to create the preferred interpretations [1] vividly. Further, interactive metadiscourse covers 5 sub-categories.

Firstly, transition markers are primarily conjunctions and adverbial phrases that allow the reader or listener to construe the pragmatic relations in every step of the argument. It represents the additive, causative, and contrastive relations within the discourse in which it helps the reader construes the relations among the ideas. The concept is elucidated into three categories [10]. Transition markers are further referred to the elements of an argument (furthermore, and, etc.), a comparison that concerns marking the argument whether it belongs to similar (in the same way, similarly, etc.) or different (however, in contrast, etc.), and consequence that functions to inform the reader or listener that the conclusion is being justified (consequently, etc.) or countered (nevertheless, etc.).

Secondly, frame markers deal with the elements of schematic structures that function to sequence, label, and shift the argument. Also, it purposes to create the discourse obvious for the readers or listeners. Therefore, it is beneficial to sequence part of the text or organizes an argument inside the text; it is also used to represent additive relations (firstly, then, etc.). Moreover, frame markers can be applied to label the text stages (to sum up, in sum, etc.). They also inform the discourse purposes (my purpose is, I argue here, etc.). Lastly, it indicates the topic shifts (let us return to, well, etc.).

Thirdly, endophoric markers concern the elements that refer to the other part of the text. It can be argued that it is a supporting element by referring to the previous material or anticipating something. It consists of additional material that is prominent, and it is enabled to aid the reader or listener in comprehending the writer's meaning. For instance, as mentioned above and see chapter 2 can be referred to as endophoric markers.

Fourthly, evidential refers to the elements that come from other texts. It deals with the representation of ideas or arguments from other sources. This element is aimed to construct an authorial command from the author and lead the reader's interpretation. It refers to the reliable source and significant supports for the argument rather than the author's stance such as according to, Hyland claims, etc.

Lastly, code glosses encompass the writer's additional information by elaborating and explaining the proportional meaning that is already stated. It functions to determine whether the reader is able or not to understand the writer's preferred meaning. Thus, it deals with the writer's prediction to know the reader's knowledge base. Several instances of code glosses are for example, such as, that is, etc.

\subsubsection{Interactional Metadiscourse}

Interactional metadiscourse deals with the interaction conducted by the writer to create explicit content and engage the readers by allowing them to respond, interpret, and evaluate the materials. It can be 
defined as a writer's delivered textually and covers how the writer conveys an assessment clearly toward the readers. Also, interactional metadiscourse engages the readers and opens the chances to contribute to the discourse by sighting them to the author's perspectives for both proportional information and readers themselves [2]. Interactional metadiscourse is further classified into 5 sub-categories.

First of all, hedges deal with the writer's decision to acknowledge alternative voices and points of view to withhold the commitment. It refers to the writer's effort to emphasize the subjectivity of information by arguing an opinion rather than open dialogue with the readers. Then, it indicates the degree of confidence. Moreover, hedges are a part of epistemic modality in which it is functioned to show an unwillingness to create an explicit and complete commitment to a proposition [11]. For instance, it is showed by auxiliary verbs, epistemic adverbs, epistemic adjectives, and lexical verbs such as might, seem, possible, etc.

Moreover, boosters concern the element that allows the writers to create a close dialogue by claiming certainty. It aims to suggest that the author narrow the diverse position rather than broaden it. Thus, closing the dialogue asserts certainty and creates a link by providing the involvement with the content and solidarity with the receiver. Similarly, it strengthens the arguments by asserting an equal experience and similar to the author's conclusion. Thus, several instances of boosters are obviously, in fact, it is clear that, etc.

Further, attitude markers attempt to indicate the writer's affective and attitude to propositions. It means that this element covers how the writer applies surprise, agreement, obligation, and so forth. Attitude is mostly expressed by attitude verbs (agree, prefer, etc.), sentence adverbs (hopefully, unfortunately, etc.) and adjectives (logical, appropriate, etc.)

Additionally, self mention deals with the explicit reference of the author's presence by the existence of first-person pronoun and possessive adjectives. The author's presence might also provide a powerful means of self-representation by giving first-person pronouns to denote personal projection. Moreover, the author's presence is also aimed to show a particular adopt stance and authorial identity. Then, several examples of self mention are mine, ours, $I$, etc.

Last, engagement markers relate to the element that explicitly creates a relationship with the reader to be part of a discourse participant. By focusing on the reader's inclusion, there are two main purposes of engagement markers [2]. First, it admits the need for the reader's expectation by addressing the reader while giving an argument with reader pronouns such as you, your, etc. and interjections such as you may notice, by the way, etc. It involves the audience being positioned rhetorically, being engaged in the discourse, and guiding the reader to the preferred interpretation. These markers are performed by questions, directives (consider, should, etc.), and references to share knowledge.

\subsection{Appraisal Theory}

The appraisal concept is used to analyze the meanings of the text that express positive or negative assessments. Assessments are influenced by the intensity or directness of such stance utterances that are strengthened or weakened [12]. It simply means that the text's meanings are contributed by the presence of positive and negative assessments that might be known from the author's stance. Thus, it is done by performing the utterances differently, strongly or weakly.

Also, regarding the assessments, those are supported by which the speakers or writers involve openly with the producer or receiver to the current proposition [12]. It can be said that positive and negative assessments are also influenced by enclosing a prior speaker or writer and audience in a particular case. This concept is called as meaning-making resources, and it is put together as the language of evaluation. Furthermore, the evaluation language deals with the speaker's or writer's personal and evaluative involvement within the text are expressed as they adopt stances to the phenomena that occur [12]

Besides, within the interpersonal metafunction model, appraisal resources work together with two interpersonal systems models [13]. Those are the communicative resources that come from the speaker or writer to show speech purposes such as responding and commanding. Furthermore, it also operates with the system of meanings conveyed by the speaker or writer to reveal greater or lesser degrees of engagement with the receiver. Subsequently, the appraisal framework is divided into three domains: attitude, engagement, and graduation [10].

Firstly, attitude deals with the representation of feelings. It covers emotional reactions, the judgment of behavior, and the evaluation of things. Further, attitude is separated into three sub-categories of feelings. They affect that deals with the resources that construe the emotional reactions whether it belongs to positive (happy, etc.) and negative ( $s a d$, etc.), the judgment that refers to the resources that evaluate behavior based on various normative principles dealing with the way people praise or criticize in responding to certain behavior such as you hypocritically claim that, etc., and appreciation that concerns on resources that construe the value of things by evaluating the semiotics and natural phenomena. It is then exemplified by the reader's evaluation of a character in the movie, such as a startlingly original character.

Secondly, engagement refers to the sourcing attitudes and the play of voices around opinions within the discourse. It simply means that engagement is related to the various comments or statements that position the speaker toward the discussed discourse. Then, the taxonomy to determine the meanings of engagement is used to identify particular positioning. It covers: Disclaim refers to the textual voice that functions to position itself as a rejection and contraries such as deny (no, never, etc.) and counter (although, 
but, etc.); Proclaim deals with the representation of textual voice to show a high warrantable such as concur (obviously, etc.), pronounce (the facts of the matter are, etc.), and endorse (the report proves that, etc.); Entertain refers to the textual voice as individual subjectivity that represents the propositions as one of the other possible positions such as probably, etc.; and Attribute deals with the representation of textual voice as an external voice such as acknowledge (Hyland argues, it states, etc.) and distance (He has claimed that, etc.).

Graduation concern with the grading of phenomena whereby the feelings are strengthened and categories blurred. It deals with the parameter that evaluates the notion of force and focus [12]. In this case, force is defined as the situation wherein the proposition's meanings are being strengthened or mitigated. Besides, force is categorized into intensification that scales the qualities, processes, and modalities, and quantification deals with assessing the amount applied to the entities.

Besides, the focus is defined as the situation scaled by the degree to which they match the semantic category's ideals instance or prototypicality. Thus, this term deals with the notion of sharpening or up-scale and soften or down-scale. In focus, it is possible to sharpen the specification so that prototypicality is denoted, such as a true friend, etc. It is also possible to soften the specification, which characterizes an example as having only marginal membership in the category, such as lazy, etc.

\section{METHOD}

This section denotes how the researcher conducts this present study, which encompasses research design, data and data source, data collection, data analysis, and data triangulation.

\subsection{Research Design}

This paper employed a constructivism worldview to conduct qualitative descriptive research investigating the phenomena of metadiscourse to allow the researcher to describe the reality behind the phenomena of metadiscourse. This paper was conducted to obtain a deep understanding of dealing with features of metadiscourse. A discourse analysis approach had been applied because it had a procedure to understand the phenomena of metadiscourse in which discourse engaged the speaker and the audience. Moreover, a discourse analysis approach was employed to collect and analyze the selected data set and fulfill the study's objectives. This approach was applied because the study dealt with the language presented by the speaker when interacting with the receiver. Accordingly, it operated in the same way as the discourse analysis to understand the meanings beyond the discourse.

\subsection{Data and Data Source}

In conducting the study, the primary data were obtained from eleven videos published by BBC News on YouTube. Before, the researcher watched the news report to classify the videos that were needed to be investigated. Before, the researcher collected 21 videos published in January. Thus, the researcher selected 11 videos that dealt with coronavirus as an object of the study. This present inquiry data were in the form of words, phrases, and parts of sentences that can be classified as interpersonal metadiscourse markers.

\subsection{Data Collection}

The primary data were collected from the selected videos posted on YouTube by $\mathrm{BBC}$ News. The technique of collecting the data was conducted throughout several steps. Firstly, the researcher selected eleven videos. Secondly, the researcher watched the news report. Thirdly, the researcher transcribed the spoken words. Fourthly, the researcher compared the transcript with the data to check the suitability. Fifthly, the researcher classified the words, phrases, and parts of sentences indicated as interpersonal metadiscourse markers. Finally, the researcher identified markers that corresponded to the appraisal framework.

\subsection{Data Analysis}

In analyzing the data, the researcher implemented several steps to analyze the data. First of all, the researcher identified the speaker's utterances from the selected news report. Then, it was done by identifying and analyzing the news report [2]. Moreover, the researcher analyzed the interpersonal metadiscourse marker, whether it referred to the sub-category of interactive or interactional metadiscourse. The researcher also merely chose the potential and appropriate data, which referred to the category of interpersonal metadiscourse.

Furthermore, the researcher employed the theory that referred to the appraisal theory to investigate its contribution to the interpersonal metadiscourse markers [10]. In this phase, to apply appraisal theory, interpersonal metadiscourse categories were not the researcher's primary concern. Instead, it focused on investigating the interpersonal metadiscourse markers, which were based on the data.

\subsection{Data Triangulation}

In this present study, triangulation was applied to figure out the validity of the data. The purpose of triangulation is to examine the data's validity through checking techniques that employ other sources outside of the data [14]. It could be defined that it needed something else that came from outside to check or 
compare the data. Therefore, this present study applied the data triangulation by engaging another researcher to check the validity. Thus, this present study attempted to involve other sources. In this case, the researcher had chosen one of the researcher's linguistics lecturer as a validator to validate the data.

\section{DISCUSSION}

This inquiry found the features of interpersonal metadiscourse markers applied by the speaker to deliver the news's arguments. The researcher revealed several markers, including transition markers, frame markers, evidential, code glosses, hedges, boosters, attitude markers, self- mention, and engagement markers [2]. Those markers were applied to help the speaker guiding and engaging the listener to be a participant within the discourse. Further, 48 data were identified as interpersonal metadiscourse markers.

This inquiry found the features of interpersonal metadiscourse markers applied by the speaker to deliver the news's arguments. The researcher revealed several markers, including transition markers, frame markers, evidential, code glosses, hedges, boosters, attitude markers, self- mention, and engagement markers [2]. Those markers were applied to help the speaker guiding and engaging the listener to be a participant within the discourse. Further, 48 data were identified as interpersonal metadiscourse markers.

First of all, the researcher found the use of transition markers that helped the speaker show the argument's steps. The researcher discovered the use of transition markers that performed additive, contrastive, and causative relations. The speaker applied the transition markers to provide extra information that helped the listener understand the additional element portrayed by the speaker through the word and as in table 1. With the requirement of transition markers to internally perform a role, the researcher found that this marker could provide a discourse role to connect the arguments internally [2].

In addition, the researcher also discovered the application of contrastive and causative relations throughout the markers. Firstly, it was showed by the presence of contrastive relations employed by the speaker through the word but with table 1 to represent the argument's contradiction. Thus, it helped the listener know the comparison between the previous ideas and continuous ideas, which guided them in comprehending the meanings. Finally, the researcher also found the indication of causative relations denoted by the speaker through table 1 that helped the listener know the relation among the two arguments. Hence, it provided the listener with the information on whether the speaker wanted to counter or justify the argument through transition markers.

Meanwhile, it was different from several previous research, [6] and [7]. It tried to figure out the frequency in using the transition markers between Native and Persian while writing the English news. Then, it explained that the markers were functioned to create the text more coherent [6]. Besides, [7] conducted research that evaluated the frequency of using transition markers, and it elucidated the presence of transition markers used to create the discourse more coherent. However, in this study, the researcher revealed the use of transition markers done by the speaker, which performed addition, comparison, and consequence that might comprehensively help the listener understand the argument's steps.

In this study, the researcher found five elements ordered by the speaker to signal the discourse boundaries. It was concerned with the words of sequence, label, shift, and predict the argument used to frame information; they were called frame markers [2]. Further, the researcher discovered the speaker's efforts to sequencing parts of the argument and shifting the topic, which corresponded to [2]'s concept.

For instance, the additive relations were first shown by the first of all, as in table 1 used by the speaker to order the argument. The second one was denoted through the word at the same as in table 1, and it explained the condition when the argument was being shifted by the speaker. Thus, the researcher concluded that the speaker applied these items to lead the listener's focus to understand the information clearly. Additionally, it was denoted the speaker's process of framing information to deliver the information obviously and communicatively.

Based on the explication above, this present study's findings merely presented the application of frame markers that functioned to sequence and shifted the speaker's argument. On the contrary, the application of frame markers by the English native writers was more frequent than Iranian writers [6]. Afterward, the data showed the use of frame markers claimed that frame markers were used by the writer to establish the text in a certain way, and therefore, it helped the reader follow the sequential and discourse acts portrayed by the writer.

According to the findings, the researcher found several sources that came from the speaker's exterior to create significant support for the speaker's argument. The sources can give reliable support for the argument, which is called evidential [2]. The researcher found several speakers who employed some ideas to strengthen their arguments by following the data, which provided the speaker to guide the listener's interpretation. For example, the marker President $X i$ says, as with table 1 , provided the speaker's argument with a strong citation.

It might involve an attribution to a reliable source that contained convincible information [2]. For this reason, the speaker attempted to persuade the listener by providing those sources to create the argument factually and reliably. Consequently, the findings revealed a persuasive goal to convince the listener, which was shown by enclosing evidential while delivering the news. Therefore, it indirectly aimed to persuade the listener about the information reported by the speaker. 
In contrast, different research [6] revealed different results with this present inquiry. They found differences in applying evidential among two news authors; they were English authors and Iranian authors. The findings showed that English authors more frequently used this marker rather than Iranian authors. Using evidence revealed that the English authors' performance in using this marker could be claimed to rely on more references and attributed the argument intertextually.

Based on the findings, the researcher found five code glosses used by the speaker to supply additional information. Thus, it was functioned to elaborate on what the speaker's said, which was applied to encourage proper understanding for the listener; it was called code glosses. By applying the marker, for example, in table 1 , the speaker wanted to help the listener understand the elaboration dealing with the previous argument. Consequently, it made the listener easy to recover the course of the information through its marker. Besides, it was done to avoid misunderstanding for the listener in following the speaker's intended meaning.

Table 1. Interactive Metadiscourse Markers

\begin{tabular}{|c|c|c|}
\hline No. & $\begin{array}{l}\text { Metadiscourse } \\
\text { Category }\end{array}$ & Data \\
\hline 1. & $\begin{array}{l}\text { Transition } \\
\text { Marker } \\
\text { (additive) }\end{array}$ & $\begin{array}{l}\text { China is battling a new and } \\
\text { rapidly spreading respiratory } \\
\text { virus }\end{array}$ \\
\hline 2. & $\begin{array}{l}\text { Transition } \\
\text { Marker } \\
\text { (contrastive) }\end{array}$ & $\begin{array}{l}\text { The authorities say it passed the } \\
\text { humans from animals at this } \\
\text { food market in the city, but if it } \\
\text { began Wuhan }\end{array}$ \\
\hline 3. & $\begin{array}{l}\text { Transition } \\
\text { Marker } \\
\text { (causative) }\end{array}$ & $\begin{array}{l}\text { We know that they will be } \\
\text { housed, therefore, people are } \\
\text { saying a period of time that } \\
\text { could be a couple of days }\end{array}$ \\
\hline 2. & Frame Marker & $\begin{array}{l}\text { The first of all to be as } \\
\text { transparent as possible to } \\
\text { release the case counts on a } \\
\text { timely manner }\end{array}$ \\
\hline 3. & Frame Marker & $\begin{array}{l}\text { We are told by officials in } \\
\text { Hubei Province this morning } \\
\text { but at the same the revealed } \\
\text { they are still struggling }\end{array}$ \\
\hline 4. & Evidentials & $\begin{array}{l}\text { And President Xi says it needs } \\
\text { be resolutely contained }\end{array}$ \\
\hline 5. & Code Glosses & $\begin{array}{l}\text { This one for example, we } \\
\text { know is telling people }\end{array}$ \\
\hline
\end{tabular}

On the other hand, this present inquiry revealed a contradiction with the relevant studies. The study [7] found that code glosses in the news reporting and news commentary indicated a low number. Further, it claimed that its application tended to denote the author's prediction regarding the existing information to the reader, which helped them understand the text. Meanwhile, it also discovered the application of code glosses [6]. English authors seemed to be more interested than Iranian authors in applying this marker to elaborate the propositional content.

Regarding the findings, the researcher found that seven devices contained a sense of subjectivity. They were portrayed by the speaker to provide a statement with plausible reasoning, as in [2] theory. As noted above, it was also claimed that hedges were commonly expressed in several categories [11]. For instance, they were epistemic verb (maybe), epistemic adjective (possible), modal verb (might), and lexical verb (seems). Consequently, the researcher found that hedges were employed to denote the speaker's speculation, the possibility of something happened, and the probability of a particular matter. Therefore, it showed the speaker's uncertainty in responding to a particular thing that caused the open dialogue since it was based on the speaker's opinion. Moreover, by using hedges, the researcher understood that the speaker tried to create an open alternative for the listener who wanted to argue regarding what the speaker said in the news.

In contrast, there were distinctions about the use of hedges from other studies [4] [6]. Firstly, it discovered the use of hedges between Persian and English editorial writers [4]. The findings denoted that English editorials applied hedges more frequently to show politeness towards their reader. Differently, other findings explained the application of hedges among two different writers [6]. It stated that Persian writers tended to feel uncertain regarding their propositions, and they were confident to create an open dialogue rather than English writers.

Following the findings, the researcher found four features that represented the certainty within the argument delivered by the speaker. They were named booster. Based on the data, it could be known that the speaker wanted to convince the listener through the presence of the word obviously, as in table 2. This corresponds to [2]'s framework, which argued that boosters allow the speakers to close any alternatives by expressing their certainty within the argument. Thus, it could be identified that the speaker attempted to deliver the information to the listener with a strong belief in responding to something. Moreover, it was done to prevent the counter from the listener and avoid the perception that raised doubts.

In comparison with the relevant studies, the results of this present study were different, which could be inspected through boosters. It was discovered that the frequency of using boosters applied by two different authors claimed that American authors were more assertive in expressing values in their writings than 
Persian authors [4]. Besides, the other study found the application of boosters in the English news reports [8]. In this study, they claimed that the use of boosters expressed the ideas that contained stressed meanings. Further, it showed several countries' reactions regarding the nuclear test by showing the opposed attitude strongly.

According to the findings, the researcher found two affective constructed by the speaker when giving the argument. This corresponds to a concept by [2], which stated that the indication of the speaker's feelings in responding to a proposition is called attitude markers. Thus, the researcher revealed that the speaker showed attitude markers through the adjective (confident) and sentence adverb (importantly). For this reason, it could be argued that the speaker wanted to perform what was being perceived by the speaker regarding the phenomena that occurred within the news.

On the contrary, it was different from previous studies conducted by [6] and [8]. It was about the use of attitude markers that helped Persian writers express their ideas, attitudes, and perspectives within the news [6]. Meanwhile, others revealed the distinction in applying attitude markers between North Korea and other countries [8]. Applying attitude markers elucidated North Korea's feeling about the nuclear test, which felt helpful for the development in that country. Nevertheless, other countries' use of attitude markers showed a refusal and worries about that nuclear test.

Based on the findings, the researcher discovered applying the first-pronouns $(I)$ and possessive adjectives (we) to show the speaker's presence. Six devices helped the speaker to project himself. This corresponds to a theory in [2], which claimed that the speaker's projection within the argument could be named as self mention. Furthermore, the researcher found the speakers' exclusion that indicated the way the speaker stood the relations with the listener. Thus, the speaker's conscious choice to clarify the involvement between the speaker and the listener.

Furthermore, in this present study, the researcher found the usage of self mention that helped the speaker impressed the authority and stood the relations by excluding the listener from the propositions. The researcher also found seven devices used by the speaker to address and include the listener named engagement markers. This corresponds to the theory in [2], which claimed that engagement markers function to highlight the listener's presence. As stated above, the researcher discovered several devices that dealt with two purposes of engagement marker. Hence, it explained how the speaker included the listener as discourse participants did by performing you, which indicated the listener's inclusion within the argument.

Moreover, the researcher also found the speaker's engagement markers' second purpose to guide the listener into a particular interpretation. They were shown through the obligation modal (have to) and imperative word (see). Therefore, the researcher claimed that this marker's application was made to pull the listeners' focus that helped them understand the discourse critically.

Additionally, in the case of exclusion and inclusion, it was claimed that a significant distinction in the application of interpersonal metadiscourse marker dealing with the possessive adjective [2]. Thus, the researcher found the distinction within the usage of the word $u s$ within the argument delivered by the speaker. Based on the findings, the pronoun $u s$, as in table 2, referred to self mention that dealt with the speaker's exclusion process. Nevertheless, in the findings, the data showed that the pronoun $u s$ in table 2 was applied to include the listener as a discourse participant identified as an engagement marker. Since this present study employed a descriptive qualitative method, it highlighted the primary aspect dealing with interpersonal metadiscourse markers, whether it belonged to self mention or engagement marker.

Table 2. Interactional Metadiscourse Markers

\begin{tabular}{|l|l|l|}
\hline No. & $\begin{array}{l}\text { Metadiscourse } \\
\text { Category }\end{array}$ & Data \\
\hline \hline 1. & Hedges & Maybe it is best not to travel \\
\hline \hline 2. & Boosters & $\begin{array}{l}\text { They are now obviously a } \\
\text { pretty concerning time for all } \\
\text { those people on board }\end{array}$ \\
\hline \hline 3. & $\begin{array}{l}\text { Attitude } \\
\text { Markers }\end{array}$ & $\begin{array}{l}\text { I am confident that our } \\
\text { government has the situation } \\
\text { well in hand }\end{array}$ \\
\hline \hline 4. & $\begin{array}{l}\text { Self Mention } \\
\text { And I can tell you, attitudes } \\
\text { here over the last 48 hours }\end{array}$ \\
\hline \hline 5. & $\begin{array}{l}\text { Self Mention } \\
\text { (exclusion) }\end{array}$ & $\begin{array}{l}\text { And those of us who work in } \\
\text { public health }\end{array}$ \\
\hline \hline 6. & $\begin{array}{l}\text { Engagement } \\
\text { Markers }\end{array}$ & $\begin{array}{l}\text { But when you consider the } \\
\text { wrong people traveling flights } \\
\text { alone }\end{array}$ \\
\hline \hline 7. & $\begin{array}{l}\text { Engagement } \\
\text { Markers } \\
\text { (inclusion) }\end{array}$ & $\begin{array}{l}\text { This is a graphic from the } \\
\text { World Health Organization } \\
\text { showing us how it's spread } \\
\text { outside of China }\end{array}$ \\
\hline
\end{tabular}

This study tried to provide significant differences in findings with the relevant studies mentioned before - the sameness and divergences in its marker application and distribution. It was discovered that the utilization of interpersonal metadiscourse markers were not merely focused on identifying the interactional metadiscourse markers. It also found several features of interpersonal metadiscourse markers applied by the speakers while giving an argument. Then, the appraisal theory was subsequently added to complete the previous studies and claimed that several markers contributed to its theory. 
Regarding the appraisal theory, the researcher discovered the contributions of appraisal theory toward the interpersonal metadiscourse markers. As noted above, the application of appraisal theory was purposed to analyze how the speaker constructed particular authorial identities that embodied its perspective within the discourse. Therefore, the findings showed the applications of appraisal theory that contributed to eleven interpersonal metadiscourse markers. It dealt with the speaker's feeling, which was called attitude and play of voice that existed within the argument, which was called engagement [10]. Further, the contributions would be explicated in the following parts.

Based on the findings, the researcher found three features that contributed to interpersonal metadiscourse markers. They were fearful, confident, and pretty balanced responses. Those features are identified as an attitude that represents the speaker's feelings [10]. It indicated the speaker's affective, whether it referred to positive (confident) or negative feelings (fear). However, in this present study, the researcher did not find any judgment. Nevertheless, the researcher discovered one feature that dealt with appreciation through the phrase pretty balanced responses. Based on the explication above, the researcher identified that those features might be attributed to interpersonal metadiscourse markers.

Furthermore, its contribution could be known by investigating the feeling perceived by the speaker. Thus, the researcher discovered that the ways the speaker mapped the feelings within the argument were indicated through emotion and aesthetics [10]. For instance, I think that this is a pretty balanced response, actually, given the circumstances. From this data, it could be comprehended how the speaker feels portrayed in responding to the response given.

Additionally, the findings also revealed the contribution of appraisal theory to several markers, which were further categorized as engagement. In this present inquiry, the researcher also discovered several features about engagement, but it merely found proclaim, entertains, and attribute. The researcher also classified the engagement's feature into more specific categories in proclaim and attribute.

Furthermore, the researcher found the contributions of appraisal theory toward boosters. They were certainly and obviously. It claimed the representation of propositions that contained a high guarantee of that propositions. Thus, the researcher discovered that those features functioned to limit the alternative actions from the ongoing discussion performed through the locutions. Moreover, they were classified as concur. The researcher found those features, and it explained the speaker's locution to announce the listener about the agreement in responding to a particular phenomenon. Consequently, it revealed the authorial voice in which the speaker shared the information with highly-positive estimation while delivering the report. Hence, it indicated how the speaker constructed the argument's meanings by performing a strong belief about what the speaker said.

By applying the appraisal theory, the researcher also found another part of the engagement that dealt with entertainment. They were maybe, possible, probably, I think, and it seems. Consequently, it contributed to hedges where it also represented the subjectivity. However, the researcher claimed that the contribution of appraisal theory explained that it created the dialogic space for those possibilities while constructing the propositions. Moreover, it recognized the proposition as one among the number of propositions available in the particular communicative context.

Finally, the researcher discovered two several features classified as an attribute. They were President $X i$ says and the British Government. By applying the appraisal theory, those features were considered as acknowledge or evidential. Therefore, the contribution of appraisal theory also came to evidential. To sum up, this contribution elucidated the speaker's effort to take responsibility for what had been said. It might be seen from reporting verb say that represented the authorial voice that stood with the proposition.

Table 3. Contributed Markers

\begin{tabular}{|c|c|c|}
\hline No. & $\begin{array}{l}\text { Appraisal } \\
\text { Domain }\end{array}$ & Data \\
\hline 1. & $\begin{array}{l}\text { Attitude } \\
\text { (affect) }\end{array}$ & $\begin{array}{l}\text { those of us who work in public } \\
\text { health have a sort of reflex fear }\end{array}$ \\
\hline 2. & $\begin{array}{l}\text { Attitude } \\
\text { (appreciation) }\end{array}$ & $\begin{array}{l}\text { I think that this is a pretty } \\
\text { balanced responses actually } \\
\text { given the circumstances }\end{array}$ \\
\hline 3. & $\begin{array}{l}\text { Engagement } \\
\text { (concur) }\end{array}$ & $\begin{array}{l}\text { And that certainly becomes very } \\
\text { complicated factor in delaying } \\
\text { the efforts of compacting the } \\
\text { virus }\end{array}$ \\
\hline 4. & $\begin{array}{l}\text { Engagement } \\
\text { (entertain) }\end{array}$ & It's possible that we have them \\
\hline 5. & $\begin{array}{l}\text { Engagement } \\
\text { (attribute) }\end{array}$ & $\begin{array}{l}\text { The British Government said it } \\
\text { was introducing a separate area } \\
\text { Heathrow Airport for people } \\
\text { travelling from affected areas }\end{array}$ \\
\hline
\end{tabular}

\section{CONCLUSION}

In accordance with the findings and discussion formerly discussed, several points that need the research's conclusion are presented. First of all, it dealt with the features of interpersonal metadiscourse markers employed by the speaker. Thus, it could be identified that transition markers, frame markers, evidential, code glosses, hedges, boosters, attitude markers, self mention, and engagement markers were employed by the speaker. However, in delivering the argument, no indication dealt 
with endophoric markers. Besides, the discussion denoted the significant distinction between self mention and engagement markers. It could be identified through the process of exclusion and inclusion in using the possessive adjective "us" in delivering an argument.

Moreover, the contribution of appraisal theory could be comprehended throughout several interpersonal metadiscourse markers applied by the speaker while giving the argument, such as evidential, hedges, boosters, attitude markers, and self mention. It explained that the appraisal theory provided several contributions to the interpersonal metadiscourse markers by evaluating how the speaker applied its feature to deliver the argument. Moreover, by applying appraisal theory, it can be identified any representation of feeling portrayed by the speaker during this pandemic era. Therefore, it elucidated the evaluation of language owned by those markers, which contributed to how the speaker constructed the meanings in delivering a statement.

\section{AUTHOR'S CONTRIBUTION}

The data of this research were collected and analyzed by Achmad Firdaus. Then, Mira Shartika, as the researcher's co-author, gave her assistance to finish the research.

\section{ACKNOWLEDGMENT}

The researchers would like to thank Irham, M. A. for his valuable insights in analyzing the data of this article.

\section{REFERENCES}

[1] K. Hyland. Metadiscourse, in: K. Tracy. C. Ilie. T. Sandel. (Eds.), The International Encyclopedia of Language and Social Interaction, 3 Volume Set, Wiley-Blackwell, Oxford, 2015. DOI: https://doi.org/10.1002/9781118611463.wbielsi003

[2] K. Hyland. Metadiscourse: Exploring interaction in writing, Continuum, 2005.

[3] J. P. Gee. M. Handford. (Eds.), The Routledge handbook of discourse analysis, Routledge, 2012.

[4] N. Tavanpour. Z. Goudarzi. M. Farnia. Interactional metadiscourse markers in sports news in newspapers: A cross-cultural study of American and Iranian columnists, vol. 1, The Philologist, 2016, pp. 1-13.
[5] S. Yazdani. S. Sharifi. M. Elyasi. A comparative study of metadiscourse markers in English and Persian news report about the September 11 event. Journal of Linguistics \& Khorasan Dialects Biannual, 8 (15), 2017, pp. 27-51. DOI: https://doi.org/10.22067/lj.v8i15.36262

[6] M. V. Farahani. M. Sabetifard. Metadiscourse features in English news writing among English native and Iranian writers: a comparative corpusbased inquiry. Theory and Practice in Language Studies, 7 (12), 2017, pp. 1249-1260. DOI: http://dx.doi.org/10.17507/tpls.0712.12

[7] L. Yan. Comparative Analysis of Russian News Reporting and News Commentary in Metadiscourse Applications, in: 2015 Conference on Informatization in Education, Management and Business (IEMB-15), Atlantis Press, 2015. DOI: https://dx.doi.org/10.2991/iemb-15.2015.223

[8] L. Wang. Y. Zhang A study of metadiscourse features in English news reports, International Journal of Arts and Commerce, 5(6), 2016, pp. 75 83.

[9] N. A. A. Abdullah. N. H. Rahmat. F. Z. Zawawi. Interactional discourse analysis of Malaysian and South Korean newspaper articles on online learning during Covid-19. European Journal of Applied Linguistics Studies, vol. 3, no. 1, 2020. DOI: https://doi.org/10.5281/zenodo.3883430

[10] J. R. Martin. P. R. R. White. The language of evaluation: Appraisal in English, Palgrave Macmillan, Hampshire, 2005.

[11] K. Hyland. Hedging in scientific research articles, vol. 54, John Benjamins Publishing, 1998.

[12] P. R. White. Appraisal theory, The international encyclopedia of language and social interaction, 2015, pp. 1-7. DOI: 10.1002/9781118611463/wbielsi041

[13] J. R. Martin. Analysing genre: Functional parameters. Genre and institutions: Social processes in the workplace and school, 1997, pp. 339.

[14] L. J. Moleong. Metode penelitian kualitatif (Revisi), ROSDA, Bandung, 2013. 